\title{
Peranan Teknologi dalam Menigkatkan Kualitas Pengajaran Bahasa di SMA Negeri 1 Janapria
}

\author{
Wildan \\ Wildannugraha1975@gmail.com \\ Program Pascasarjana UIN Mataram
}

Received: Oktober 2021

Accepted: November 2021

Online Published: Desember 2021

\begin{abstract}
This study aims to determine the role of technology in improving the quality of language teaching at SMAN 1 Jaanapria. This type of research is quantitative and qualitative research. The research method used combines qualitative and quantitative methods (mix methods). The data obtained from this study were from interviews and observations and data obtained from questionnaires/questionnaires. There are two elements studied in the data analysis: the element of student learning motivation and the element of the role of technology in language learning. From the discussion, it can be concluded that the student's learning motivation in class averages $65.5 \%$, meaning that students at SMAN 1 Janapria on average often pay attention to teachers in class. Besides that, students also desire to solve problems and discuss them with others. Other students for the learning process. While the role of language learning technology is an average of 56.3\%, meaning that students and educators, especially teachers, sometimes use technology in the language learning process. Students think technology is needed to support the language teaching and learning process in the classroom.
\end{abstract}

Keywords: Technology, Quality, and Teaching

Abstrak

Penelitian ini bertujuan untuk mengetahui peranan teknologi dalam meningkatkan kualitas pengajaran bahasa pada SMAN 1 Jaanapria. Jenis penelitian ini adalah penelitian kuantitatif dan kualitatif.Metode penelitian yang digunakan adalah metode gabungan antara kualitatif dan kuantitatif ( mix methods). Data yang diperoleh dari penelitian ini dari hasil wawancara dan observasi, serta data yang didapatkan dari kuisioner/angket. Ada dua unsur yang dikaji dalam analisis data yaitu unsur motivasi belajar siswa dan unsur peran teknologi dalam pembelajaran bahasa. Dari pembahasan dapat disimpulkan bahwa di dapat bahwa motivasi belajar siswa di kelas rata-rata memiliki 65,5\% artinya para siswa di SMAN 1 Janapria rata-rata sering memperhatikan guru di kelas dan selain itu para siswa juga memiliki keinginan untuk memecahkan masalah dan berdiskusi kepada para siswa lain untuk proses pembelajaran. Sedangkan peran teknologi pembelajaran bahasa rata-rata 56,3\%, artinya siswa dan pendidik khususnya guru terkadang menggunakan teknologi dalam proses pembelajaran bahasa dan peserta didik beranggapan bahwa teknologi sangat diperlukan untuk mendukung proses belajar mengajar bahasa di kelas.

Kata Kunci : Teknologi, Kualitas dan Pengajaran

\section{PENDAHULUAN}

Perkembangan teknologi dewasa ini memberikan dampak yang besar bagi kehidupan masyarakat secara umum, baik dalam disiplin ilmu sosial, politik, hukum, pendidikan maupun budaya. Karena masyarakat dituntut untuk memahami penggunaan teknologi, teknologi telah menjadi kebutuhan penting yang dirasakan baik oleh lingkungan maupun masyarakat perkotaan dari waktu ke waktu. Hal ini melahirkan berbagai inovasi dan kreativitas dalam pemanfaatan teknologi yang dapat menunjang berbagai kegiatan, termasuk di bidang pendidikan.Mengingat pendidikan merupakan faktor penting dalam memajukan kecerdasan bangsa Indonesia, maka 
pemerintah saat ini memprioritaskan peningkatan kualitas pendidikan. Proses pembelajaran dalam dunia pendidikan merupakan interaksi antara siswa dan guru untuk menyampaikan pengetahuan dengan menggunakan cara-cara tertentu agar pengetahuan tersebut dapat diserap dengan baik oleh khalayak. Menurut (Sapto, 2009) belajar pada hakikatnya adalah proses komunikasi yang bertujuan untuk menyampaikan pesan/informasi yang dapat merangsang pikiran, perasaan dan perhatian siswa. Guru bertugas mentransfer ilmu, menghasilkan pengalaman belajar bagi siswa, dan melakukan penilaian bagi siswa (Rohmadi, 2021). Guru selalu dapat memberikan kesempatan kepada siswa untuk secara aktif mengintervensi proses belajar mengajar. Nantinya akan digunakan di papan tulis dan buku sebagai pedoman pengajaran untuk kehidupan sehari-hari di depan kelas. Menurut (Sudarsana, 2017) menjelaskan bahwa metode ceramah adalah metode yang digunakan guru kepada siswanya untuk menyampaikan materi secara lisan di kelas. Menurut penelitian yang dilakukan oleh (Muhson, 2010), ketika belajar dalam format ceramah, siswa hanya dapat menyerap 5 materi yang diberikan oleh guru, tetapi $90 \%$ dari kegiatan pembelajaran dilakukan dengan rekan kerja. Dalam proses pembelajaran peran teknologi diperlukan sebagai sumber dalam belajar (Fahrezi, 2021).

Berdasarkan pemikiran tersebut, diperlukan inovasi yang dapat dikembangkan untuk meningkatkan kualitas pendidikan dalam proses pendidikan dan pembelajaran. Pembelajaran aktif terinspirasi oleh berbagai penggunaan pembelajaran aktif, inovatif, kreatif, dan menyenangkan untuk membantu siswa bersantai dan menerima pelajaran dengan cepat. Salah satu inovasi yang digunakan ialah pemanfaatan media teknologi informasi yang merupakan media pembelajaran modern. Upaya yang dilakukan juga tidak terlepas dari campur tangan pihak sekolah (Triyanto, Eko; Anitah, 2013) yang menegaskan bahwa penggunaan media pembelajaran berpengaruh positif terhadap proses belajar mengajar untuk membantu siswasiswa, menawarkan topik yang dinamis dan tidak monoton.

Umumnya teknologi informasi dan komunkasi (TIK) mempunyai makna yang berbeda. (Rhoger, 1986) mengatakan bahwa teknologi informasi berarti peralatan perangkat keras atau hardware, struktur organisasi dan nilai-nilai sosial di mana individu dapat mengumpulkan, memperoses dan berbagi informasi dengan orang lain. Sedangkan teknologi komunikasi adalah semua yang meliputi system komunikasi, seperti satelit transmisi langsung, kabel interaktif dua arah, transmisi berdaya rendah, dan televise (termasuk video disc dan videotape). Komunikasi modern kini telah dipadukan dengan teknologi dan komunikasi berupa telepon selular seperti smartphone, android, conference call, dan sarana komunikasi lainnya. Dengan kemajuan teknologi baik teknologi informasi maupun teknologi komunikasi, hal ini dapat mendukung peningkatan kualitas pendidikan. Salah satu peningkatan kualitas yang paling penting adalah pembelajaran bahasa, karena sebagian besar pelajar bahasa berjuang untuk menyampaikan keterampilan bahasa mereka kepada siswa. Peranan teknologi dalam membantu meningkatkan kualitas pendidikan agar proses pembelajaran dapat membuat proses menjadi lebih menyenangkan. (Sapto, 2009) mengatakan bahwa kemajuan teknologi, khususnya teknologi 
informasi dan komunikasi, menawarkan banyak kemudahan dalam belajar siswa yang memungkinkan terjadinya perubahan orientasi belajar dari proses penyajian pengetahuan yang beragam ke proses konseling dalam melakukan eksplorasi sains secara individu. Cara atau teknik pengajaran yang dilakukan oleh tenaga pendidik lebih cenderung mengunakan media teknologi informasi yaitu sistem penmbelajaran yang memanfaatkan perangkat keras ( hardware) dan perangkat lunak (software) dalam sistem pembelajaran yang akan dilaksankan. Ada beberapa contoh yang telah dilakukan untuk meningkatkan kualitas pendidikan melalui pemanfaatan teknologi informasi. (Marzal, 2014) mengatakan bahwa teknologi informasi dapat membantu mentransformasikan sistem pembelajaran siswa tunarungu melalui penggunaan media visual dalam pembelajaran. (Kwartolo, 2010) menyatakan bahwa penggunaan teknologi dalam pembelajaran bahasa Inggris dapat membantu guru berinteraksi dengan pembelajaran siswa, termasuk penggunaan teknologi komputer. Misalnya, seorang guru dapat mentransfer file/materi dari komputer ke ruang kendali utama, selain itu tenaga pendidik dapat melatih intonasi dan pengucapan bahasa inggris dengan menggunakan perangkat lunak DDL teacher dan $D D L$ student. Pembelajaran yang bersifat dinamis tidak akan pernah menutup adanya perubahan dalam meningkatkan kualitas mutu pendidikan.

Contoh mata pelajaran yang bisa meningkatkan kemampuan psikomotor dan dan kognitiv peserta didik adalah pendidikan bahasa, apakah bahasa Indonesia atau bahasa inggris, karena bahasa merupakan alat untuk mengkomunikasikan ide, gagasan, pendapat serta informasi kepada orang lain. Bahasa yang benar membutuhkan ejaan yang canggih (EYD). Pembelajaran bahasa dianggap penting karena dikaitkan dengan praktik komunikasi yang menggunakan bahasa yang digunakan dalam kehidupan sehari-hari. (Fridani, Lara; Dhieni, 2014), menerangkan bahwa bahasa adalah simbol yang digunakan untuk berkomunikasi dengan orang lain untuk membuat berbagai jenis komunikasi. Kalimat bermakna yang mudah dipahami oleh yang diajak berkomunikasi. Penggunaan bahasa menurut kurikulum tidak lepas dari beberapa prinsip: 1) Ada hubungan antara empat aspek berbahasa: menyimak, berbicara, membaca, dan menulis. 2) Sastra/literatur sangat penting dalam kegiatan berbahasa,sebagai kontributor penting untuk empat aspek bahasa tersebut. 3) Penggunaan bahasa secara ilmiah dapat dilakukan bersamaan dengan penelitian di bidang pengetahuan lainnya. Hal ini menunjukkan bahwa pembelajaran bahasa tidak hanya bersifat teoritis, tetapi juga memerlukan latihan menggunakan kreativitas dan inovasi agar siswa dapat menyerapnya dan memasukkannya ke dalam kehidupan masyarakat..

Sebagian besar daerah yang masih berada pada wilayah 3T (terpencil) masih merasa kesulitan di dalam mempelajarinya, sebab yang dipergunakan setiap hari adalah bahasa daerah. Beberapa Kecamatan yang ada di Kabupaten Lombok Tengah yang salah satunya adalah wilayah kecamatan Janapria. Kebanyakan masyarakat secara umum masih menggunakan bahasa daerah didalam melakukan komunikasi. SMA Negeri 1 Janapria Lombok Tengah merupkan sekolah yang memiliki tujuan dalam peningkatan dan pembinaan dalam menumbuhkembangkan mutu sekolah serta potensi peserta didik yang ada diantaranya 
kemampuan kognitiv, psikomotorik dan afektif, untuk menuju hidup yang mandiri. Tujuan sekolah yang tercantum pada dokumen SMAN 1 Janapria adalah :

1. Membentuk peserta didik yang bertaqwa ,berbudi pekerti luhur dan taat terhadap norma agama , Negara dan norma yang berlaku di masyarakat.

2. Meningkatkan kualitas/mutu akademik sehingga dapat diterima di perguruan tinggi

3. Meningkatkan prestasi peserta didik dalam bidan non akademik

4. Membentuk karakter peserta didk agar menjadi kreatif dan mampu mengekspresikan bakat dan minatnya lewat kegiatan-kegiatan ekstakurikuler lainnya

5. Meningkatkan pengetahuan, keterampilan dan kemampuan siswa dalam hidup mandiri sehingga mampu mengatasi tantangan hidup yang semakin keras di masyrakat

SMA Negeri 1 Janapria juga memiliki beberapa fasilitas cukup memadai dan letak geografis sekolah berada pada ibu kota kecamatan. Oleh karena itu penelitian ini dilakukan disalah satu sekolah yang ada di daerah Janapria yaitu SMA Negeri 1 Janapria, Lombok Tengah untuk mengetahui jalan mana yang harus ditempuh dan apa peran teknologi dalam meningkatkan kualitas pembelajaran bahasa, khususnya bahasa Inggris dan bahasa Indonesia di sekolah.

\section{METODE PENELITIAN}

Jenis dan metode pada penelitian ini adalah kualitatif dan kuantitatif ( campuran ). Metode kualitatif digunakan untuk mempelajarai kondisi objektif alami (sebagai lawan dari metode eksperimen ). Hasil penelitian kualitatif lebih signifikan daripada data yang diperoleh (Suryana, 2010). Untuk metode kualitatif pada penelitian ini data yang diperoleh dari hasil wawancara dan observasi. Wawancara bertujuan untuk mengkaji informasi yang tersedia tentang penggunaan teknologi dalam pembelajaran bahasa ( bahasa Inggris dan bahasa Indonesia ) dan keterampilan guru untuk menangani media teknologi tersebut, sedangkan observasi digunakan untuk mengamati secara langsung penggunaan teknologi dalam pembelajaran bahasa oleh guru dikelas. Wawancacara dilakukan dengan 4 orang di SMAN 1 Janapria Lombok Tengah yaitu kepala sekolah, wakil kepala sekolah urusan kurikulum, guru bahasa Indonesia, guru bahasa Inggris, dan hasil dari proses wawancara dijadikan menjadi data pendukung untuk data kuantitatif atau sering disebut dengan mix methode.

Sedangkan untuk metode kuantitatif juga sering dinamakan dengan metode tradisional karena sudah digunakan sejak lama, hasil dari masing-masing variable disajikan dalam bentuk angka-angka atau numerik serta menggunakan statistik (Suryana, 2010).Data yang didapatkan dari data kuantitatif tersebut berasal dari data yang diperoleh dengan menggunakan angket atau kuesioner yang bersumber dari beberapa pertanyaan. Dalam instrumen yang digunakan,pertanyaan yang diberikan bertujuan untuk melihat motivasi peserta didik dalam pembelajaran serta melihat kemampuan mereka dalam penggunaan teknologi informasi terhadap pembelajaran bahasa baik itu pembelajaran bahasa Indoneia maupun pembelajaran bahasa 
Inggris di SMAN 1 Janapria. Kuesioner/angket diberikan kepada para siswa siswi kelas X ( sepuluh ). Selanjutnya data yang diperoleh akan dianalisis untuk memperoleh gambaran yang jelas terkait dengan maksud dari penelitian ini. Adapun langkah-langkah dalam analisis data pada penelitian ini yaitu :

1. Tabulasi adalah penyususnan data kedalam tabel yang mana bertujuan agar data dapat dengan mudah disusun maupun dijumlah;

2. Input data dengan memasukan data yang ada diangket ke aplikasi dalam hal ini yaitu menggunakan Microsoft Excel dan SPSS 16

3. Coding data, dimana data disetiap pertanyaan akan diberikan kode agar dapat dengan mudah dilakukan perhitungan

4. Pengelompokan data dalam kuesioner dikelompokan sesuai dengan kode yang telah tentukan pada langkah sebelumnya

5. Dikalkulasi dengan menggunakan skala likert.

Skala Likert adalah skala penelitian yang digunakan untuk mengukur sikap dan pendapat. Dengan skala likert ini, responden diminta untuk melengkapi kuesioner yang mengharuskan mereka untuk menunjukkan tingkat persetujuannya terhadap serangkaian pertanyaan. Pertanyaan atau pernyataan yang digunakan dalam penelitian ini biasanya disebut dengan variabel penelitian dan ditetapkan secara spesifik oleh peneliti. (Budiaji, 2013) menjelaskan bahwa ada beberapa penelitian yang menggunakan pengukuran dengan skala Likert sebagai skala interval, sebagai contoh misalnya pengukuran kebiasaan makan yang sehat, di mana analisis dilakukan untuk mengetahui perkiraan keseluruhan jumlah tanggapan dari setiap pertanyaan -pertanyaan yang dberikan. Skala Likert digunakan untuk mengukur kesetujuan dan ketidaksetujuan seseorang terhadap sesuatu rencana program, pelaksanaan program ataupun tingkat keberhasilan suatu program.

Tabel 1. Skala likert

\begin{tabular}{clc}
\hline No & \multicolumn{1}{c}{ Pernyataan } & Skor \\
\hline 1 & Tidak Pernah ( TP) & 1 \\
2 & Jarang ( J) & 2 \\
3 & Kadang-Kadang (KK) & 3 \\
4 & Sering (S) & 4 \\
5 & Selalu (S) & 5 \\
\hline
\end{tabular}

Adapun beberapa langkah perhitungan dengan menggunakan skala likert (Much, I., Subroto, I., Farisa, S., \& Haviana, 2016) yaitu :

1. Menentukan skala jawaban lebih dahulu

2. Menentukan nilai skor kriterium

Dimana Skor kriterium = nilai skala jawaban $\mathrm{x}$ jumlah responden

3. Setelah skor kriterium masing-masing skala didapatkan, tentukan nilai rating skala 


$$
\begin{aligned}
& \text { Batas atas }=\text { skor kriterium } \\
& \text { Batas bawah } S K D=\text { batas bawah terendah } \\
& \text { Batas bawah } K D=\text { batas atas } S K D+1 \\
& \text { Batas bawah } C D=\text { batas atas } K D+1 \\
& \text { Batas bawah } D=\text { batas atas } C D+1 \\
& \text { Batas bawah } S D=\text { batas atas } D+1
\end{aligned}
$$

4. Mencari hasil dari masing - masing pertanyaan untuk masing-masing kriteria jawaban

$$
\text { Hasil = frekuensi kemunculan jawaban } x \text { skala }
$$

5. Setelah diperoleh hasil dari masing-masing skala jawaban, maka seluruh hasil akan dijumlahkan

$$
\text { Skor akhir }=\frac{\text { Hasil } S D+\text { hasil } D+\text { hasil } K D+\text { hasil } C D}{\text { Nilai skala terbesar }} \times 100
$$

Skor akhir digunakan untuk menentukan arah jawaban untuk sebuah pertanyaan, dan skor akhir akan dibandingkan dengan data skala penilaian yang berasal dari skor dasar.

6. Kesimpulan dari hasil akhir setiap pertanyaan dirangkum dan dirata-ratakan sehingga data dapat dianalisis.

Tempat penelitian dilakukan di SMAN 1 Janapria, Kabupaten Lombok Tengah dimana lokasi ini dipilih untuk mendapatkan informasi seputar peranan penggunaan tekhnologi dalam pembelajaran bahasa

\section{HASIL DAN PEMBAHASAN}

\section{Hasil}

Penelitian yang dilakukan di SMAN 1 Janapria, yang pada garis besarnya inigin mengetahui peranan teknologi dalam meningkatkan kualitas pengajaran bahasa, di tunjukkan dengan gambaran seperti di bawah ini. Untuk mempermudah dalam penjabaran data yang diperoleh pada data kuantitatif dalam sebaran kuisioner atau angket dalam penelitian ini, serta untuk mengetahui hubungan dari penelitian dalam meningkatkan mutu pendidikan pembelajaran bahasa, yaitu dari masing-masing pertanyaan diberikan kode , pengkodeannya seperti terlihat pada tabel dibawah ini : 
Tabel 2. Daftar kode sebaran kuisioner

\begin{tabular}{lll}
\hline No & \multicolumn{1}{c}{ Pertanyaan } & Kode \\
\hline 1 & Apakah anda selalu memperhatikan Guru mengajar didepan kelas ? & A1 \\
2 & $\begin{array}{l}\text { Apakah dalam penyampaian materi di kelas sangat menyenangkan? } \\
\text { Apakah Guru menggunakan media teknologi informasi pada pembelajran }\end{array}$ & A2 \\
3 & B1 \\
& $\begin{array}{l}\text { Bahasa? } \\
\text { Apakah di sekolah terdapat media teknologi informasi untuk membantu }\end{array}$ & B2 \\
& $\begin{array}{l}\text { mencari informasi materi pelajaran Bahasa? } \\
\text { Apakah Guru pernah menggunakan video visual untuk menerangkan }\end{array}$ & B3 \\
dst & pembelajaran bahasa di kelas? & \\
\hline
\end{tabular}

Setelah semua pertanyaan diberikan kode kemudian menentukan kriteria penilaian dari jawaban yang diisi oleh para responden dengan penentuan sebagai berikut :

Tabel 3. Daftar kriteria dan sakala nilai

\begin{tabular}{lc}
\hline Skala Jawaban & Nilai Skala \\
\hline Selalu Sering & 5 \\
Sering & 4 \\
Kadang-Kadang & 3 \\
Jarang & 2 \\
Tidak Pernah & 1 \\
\hline
\end{tabular}

Semua jawaban yang dibuat oleh para responden akan diinput sesuai dengan nilai skala yang dibuat. Setelah dijabarkan maka dibuat rating skala dengan hasil seperti dibawah ini :

Tabel 4. Daftar rating skala

\begin{tabular}{cccccc}
\hline Skala & $\begin{array}{c}\text { Jml } \\
\text { responden }\end{array}$ & Nilai skala & $\begin{array}{c}\text { Skor } \\
\text { Kriterium }\end{array}$ & $\begin{array}{c}\text { Nilai } \\
\text { Jawaban }\end{array}$ & $\begin{array}{c}\text { Persentase } \\
\text { Jawaban }\end{array}$ \\
\hline SS & 38 & 5 & 190 & $153-190$ & $80 \%-100 \%$ \\
S & 38 & 4 & 152 & $115-152$ & $60 \%-79,99 \%$ \\
KK & 38 & 3 & 114 & $77-114$ & $40 \%-59,99 \%$ \\
J & 38 & 2 & 76 & $39-76$ & $20 \%-39,9 \%$ \\
TP & 38 & 1 & 38 & $0-38$ & $0-19,9 \%$ \\
\hline
\end{tabular}

Tabel 4 menunjukkan hasil skor kriterium yang diperoleh dimana jumlah respondennya adalah sebanyak 38 orang. Menurut rumus perhitungan, skala "Sangat Sering"' memperoleh skor 190, skala "Sering"' skor 152, skala 'Kadang-Kadang'" skor 114, skala "Jarang" skor 76 dan skala "Tidak Pernah" diperoleh skor 38. Data kriteria juga menunjukkan skala penilaian, yaitu untuk jawaban "'sangat sering'" nilainya antara 153-190, skala 'sering"' antara 115-152, skala 'kadang-kadang'" nilainya berkisaran antara 77-114, skala 'jarang", nilainya berkisaran antara 39-76 dan skala 'tidak pernah" nilainya berkisaran antara 0-38. 
Masing-masing pertanyaan yang disampaikan pada angket maka didapat frekuensi skala jawaban yang diberikan oleh para responden yang dapat dilihat pada tabel berikut ini, dengan menampilkan sampel dari pertanyaan yang diajukan :

a. Motivasi belajar siswa di kelas

Tabel 5. Daftar frekwensi jawaban motivasi belajar

\begin{tabular}{|c|c|c|c|c|c|c|}
\hline Kode & Pertanyaan & SS & $\mathbf{S}$ & KK & $\mathbf{J}$ & TP \\
\hline A1 & $\begin{array}{l}\text { Apakah saudara selalu memperhatikan Guru } \\
\text { mengajar didepan kelas? }\end{array}$ & 20 & 14 & 4 & 0 & 0 \\
\hline A2 & $\begin{array}{l}\text { Apakah dalam penyampaian materi dikelas } \\
\text { sangat menyenangkan? }\end{array}$ & 11 & 10 & 16 & 1 & 0 \\
\hline A3 & $\begin{array}{l}\text { Apakah bahan pelajaran didalam kelas sesuai } \\
\text { dengan pengalaman yang saudara alami? }\end{array}$ & 1 & 10 & 15 & 7 & 5 \\
\hline A4 & $\begin{array}{l}\text { Apakah saudara memiliki perasaan tertarik } \\
\text { terhadap pelajaran yang ada? }\end{array}$ & 15 & 12 & 11 & 0 & 0 \\
\hline A5 & $\begin{array}{l}\text { Apakah saudara meminta bantuan dalam } \\
\text { setiap kesulitan yang saudara alami dalam } \\
\text { pelajaran? }\end{array}$ & 3 & 5 & 21 & 6 & 3 \\
\hline A6 & $\begin{array}{l}\text { Apakah saudara punya keinginan untuk } \\
\text { menyelesaikan kesulitan sendiri mengenai } \\
\text { pelajaran dikelas? }\end{array}$ & 9 & 12 & 9 & 5 & 3 \\
\hline A7 & $\begin{array}{l}\text { Apakah saudara merasa putus asa ketika } \\
\text { menghadapi kesulitan dalam belajar? }\end{array}$ & 0 & 3 & 5 & 2 & 28 \\
\hline A8 & $\begin{array}{l}\text { Apakah saudara merasa bosan dengan tugas } \\
\text { yang diberikan di sekolah? }\end{array}$ & 3 & 3 & 9 & 2 & 21 \\
\hline A9 & $\begin{array}{l}\text { Apakah saudara mempunyai rasa ingin tahu } \\
\text { yang tinggi dalam belajar di kelas? }\end{array}$ & 15 & 15 & 7 & 0 & 1 \\
\hline A 10 & $\begin{array}{l}\text { Apakah saudara berdiskusi dengan teman- } \\
\text { teman dalam memecahkan masalah belajar? }\end{array}$ & 8 & 11 & 10 & 7 & 2 \\
\hline
\end{tabular}

b. Peranan teknologi dalam pembelajaran bahasa

Tabel 6. Daftar frekwensi jawaban peranan teknologi

\begin{tabular}{|c|c|c|c|c|c|c|}
\hline Kode & Pertanyaan & SS & $\mathrm{S}$ & KK & $\mathbf{J}$ & TP \\
\hline B1 & $\begin{array}{l}\text { Apakah Guru menggunakan media teknologi } \\
\text { informasi pada pembelajaran Bahasa }\end{array}$ & 3 & 3 & 16 & 7 & 9 \\
\hline B2 & $\begin{array}{l}\text { Apakah di sekolah terdapat media teknologi } \\
\text { informasi untuk membantu mencari } \\
\text { informasi materi pelajaran bahasa? }\end{array}$ & 2 & 3 & 11 & 5 & 17 \\
\hline B3 & $\begin{array}{l}\text { Apakah Guru pernah menggunakan video } \\
\text { visual untuk menerangkan pembelajaran } \\
\text { bahasa dikelas? }\end{array}$ & 6 & 10 & 12 & 1 & 9 \\
\hline B4 & $\begin{array}{l}\text { Menurut saudara apakah perlu adanya } \\
\text { teknologi untuk membantu proses belajar } \\
\text { mengajar bahasa di kelas? }\end{array}$ & 12 & 13 & 6 & 3 & 4 \\
\hline B5 & $\begin{array}{l}\text { Apakah saudara memiliki ketertarikan } \\
\text { menggunakan teknologi sebagai media } \\
\text { pembelajaran bahasa? }\end{array}$ & 13 & 16 & 4 & 3 & 2 \\
\hline
\end{tabular}


c. Peranan teknologi dalam pembelajaran bahasa

Tabel 6. Daftar frekwensi jawaban peranan teknologi

\begin{tabular}{|c|c|c|c|c|c|c|}
\hline Kode & Pertanyaan & SS & $\mathbf{S}$ & KK & $\mathbf{J}$ & TP \\
\hline B1 & $\begin{array}{l}\text { Apakah Guru menggunakan media teknologi } \\
\text { informasi pada pembelajaran Bahasa }\end{array}$ & 3 & 3 & 16 & 7 & 9 \\
\hline B2 & $\begin{array}{l}\text { Apakah di sekolah terdapat media teknologi } \\
\text { informasi untuk membantu mencari } \\
\text { informasi materi pelajaran bahasa? }\end{array}$ & 2 & 3 & 11 & 5 & 17 \\
\hline B3 & $\begin{array}{l}\text { Apakah Guru pernah menggunakan video } \\
\text { visual untuk menerangkan pembelajaran } \\
\text { bahasa dikelas? }\end{array}$ & 6 & 10 & 12 & 1 & 9 \\
\hline B4 & $\begin{array}{l}\text { Menurut saudara apakah perlu adanya } \\
\text { teknologi untuk membantu proses belajar } \\
\text { mengajar bahasa di kelas? }\end{array}$ & 12 & 13 & 6 & 3 & 4 \\
\hline B5 & $\begin{array}{l}\text { Apakah saudara memiliki ketertarikan } \\
\text { menggunakan teknologi sebagai media } \\
\text { pembelajaran bahasa? }\end{array}$ & 13 & 16 & 4 & 3 & 2 \\
\hline B6 & $\begin{array}{l}\text { Apakah saudara pernah belajar menggunakan } \\
\text { teknologi visual/video dalam pembelajaran } \\
\text { bahasa selain di kelas? }\end{array}$ & 6 & 4 & 9 & 7 & 12 \\
\hline B7 & $\begin{array}{l}\text { Apakah saudara pernah menggunakan } \\
\text { teknologi internet untuk mencari informasi } \\
\text { materi pembelajaran bahasa? }\end{array}$ & 2 & 1 & 3 & 7 & 25 \\
\hline B8 & $\begin{array}{l}\text { Apakah anda menggunakan internet saat } \\
\text { menyelesaikan tugas khusus bahasa? }\end{array}$ & 2 & 3 & 1 & 3 & 29 \\
\hline B9 & $\begin{array}{l}\text { Pernahkah anda kesulitan mencari informasi } \\
\text { tentang pembelajaran bahasa menggunakan } \\
\text { teknologi? }\end{array}$ & 2 & 12 & 14 & 6 & 4 \\
\hline B10 & $\begin{array}{l}\text { Apakah saudara memiliki keinginan untuk } \\
\text { menggunakan teknologi dalam } \\
\text { menyelesaikan masalah dalam pembelajaran } \\
\text { bahasa? }\end{array}$ & 16 & 12 & 7 & 2 & 1 \\
\hline
\end{tabular}

Terdapat 2(dua) jenis pertanyaan pada angket yang di sebarkan, yaitu pertanyaan pertama tentang motivasi belajar siswa di kelas, dan pertanyaan kedua adalah tentang peranan teknologi dalam pembelajaran bahasa. Pada tabel 5 menunjukkan bahwa untuk pertanyaan pertama tentang "apakah saudara selalu memperhatikan guru mengajar didepan kelas "terdapat frekuensi pada jawaban 'SS' adalah 20 responden, frekuensi jawaban " $S$ ", adalah 14 responden, frekuensi jawaban ' $K K$ ', adalah 4 responden, frekuensi jawaban 'J" adalah 0 responden dan frekuensi jawaban 'TP' adalah 0 responden. Begitu juga untuk pertanyaan lainnya bisa di lihat pada tabel 5 dan pada tabel 6 di atas. Dari data pada tabel 5 dan tabel 6 diatas dengan menggunakan skala nilai rata-ratanya, maka didaptkan hasil dari pertanyaan pertama dan pertanyaan kedua adalah sebagai berikut :

Tabel 7. Daftar persentase jawaban responden

\begin{tabular}{lll}
\hline No & Pertanyaan & Persentase \\
\hline 1 & Motivasi belajar siswa di kelas & $65,5 \%$ \\
2 & Peranan teknologi dalam pembelajaran bahasa & $56,3 \%$ \\
\hline
\end{tabular}

Berdasarkan hasil persentase rata-rata pada Tabel 7, di dapat bahwa motivasi belajar siswa di kelas rata-rata memiliki 65,5\% artinya para siswa di SMAN 1 Janapria rata-rata sering memperhatikan guru di kelas dan selain itu para siswa juga memiliki keinginan untuk memecahkan masalah dan berdiskusi kepada para siswa lain untuk proses pembelajaran. Para siswa juga lebih merasa tertarik dengan pelajaran yang ada di kelas karena penyampaian 
materi yang disampaikan oleh para guru sangat menyenangkan sehingga dapat disimpulkan bahwa para siswa memiliki motivasi belajar yang tinggi.

Sedangkan peran teknologi pembelajaran bahasa rata-rata $56,3 \%$, artinya siswa dan pendidik khususnya guru terkadang menggunakan teknologi dalam proses pembelajaran bahasa. Dari saran-saran hasil angket, para siswa malah beranggapan bahwa teknologi sangat diperlukan untuk mendukung proses belajar mengajar bahasa di kelas, siswa juga sering mengalami kesulitan dalam mencari bahan yang digunakan untuk menyelesaikan tugas pada mata pelajaran bahasa yang dikarenakan masih kurangnya jaringan teknologi internet di daerah Janapria Lombok Tengah.

Selain itu untuk mendukung analisis data yang digunakan dengan data kuantitatif, maka peneliti juga menggunakan metode kualitatif dalam hal ini menggunakan teknik wawancara. Wawancara ini dilakukan dengan beberapa unsur di sekolah yang bersangkutan, yaitu Kepala sekolah, wakil kepala sekolah urusan Kurikulum, guru bahasa Indonesia dan guru bahasa Inggris. Hasil dari wawancara tersebut menyatakan bahwa di sekolah sudah menggunakan beberapa perangkat teknologi untuk mendukung proses pembelajaran di sekolah misalnya guru sudah menggunakan proyektor dalam penyampaian materi di kelas, sudah menggunakan aplikasi pembelajaran seperti class room, $\mathrm{G}$ meet dan lain sebagainya. Namun ada beberapa kendala yang dialami oleh guru-guru di SMAN 1 Janapria yaitu masih kurang stabilnya jaringan pendukung yang ada dan masih kurangnya pemahaman tentang pengembangan bahan ajar yang berbasis teknologi..

Sedangkan Guru Bahasa Inggris dan Bahasa Indonesia SMAN 1 Janapria juga mengatakan bahwa dalam pembelajaran sudah menggunakan media elektronik seperti LCD proyektor serta penggunaan dengan Microsoft power point, serta penerapan aplikasi-aplikasi media pembelajaran lainnya.

\section{Pembahasan}

Penelitian ini mengguanakan jenis dan metode penelitian campuran ( mix methods ) yaitu jenis penelitian kuantitatif dan kualitatif yang bertujuan untuk mengetahui peranan teknologi dalam meningkatkan kualitas pengajaran bahasa di SMAN 1 Janapria. Penelitian dilakukan dengan menggunakan angket (kuesioner) sebagai alat pengumpul data serta wawancara sebgai pendukung dari dati yang didapatkan dari data kuantitatif.

a. Motivasi belajar siswa di kelas.

Dari data angket/kuisioner yang didapatkan, gambaran yang disajikan menunjukkan bahwa, responden yang berjumlah 38 orang dengan gambarannya adalah angket dan kuesioner yang disebarkan terdapat dua jenis pertanyaan yaitu tentang motivasi belajar siswa di kelas dan tentang peranan teknologi dalam pembelajaran bahasa. Pada data yang disajikan pada tabel 5 di atas menunjukkan bahwa untuk pertanyaan pertama frekuensi pada skala jawaban ' SS' yaitu 20 orang, frekuensi skala jawaban ' 'S', adalah 14 orang, frekuensi skala untuk jawab 'KK' adalah 4 orang, frekuensi skala jawaban 'J" adalah 0 dan frekuensi skala jawaban 'TP', adalah 0. Data frekuensi jawaban responden tersebut didapatkan bahwa motivasi belajar siswa di kelas rata-rata dengan persentase 65,5\% artinya bahwa para siswa di SMAN 1 Janapria rata-rata sering 
memperhatikan guru di kelas dan para siswa juga memiliki keinginan untuk memecahkan masalah dan berdiskusi dengan peserta didik lainnya dalam melakukan proses pembelajaran.Para peserta didik merasa lebih tertarik dengan pelajaran bahasa di kelas, karena penyampaian materi yang baik dari guru, sehingga dapat disimpulkan bahwa para siswa memiliki motivasi belajar yang tinggi dalam pembelajaran di kelas.

b. Peranan teknologi dalam pembelajaran bahasa

Sedangkan peran teknologi pembelajaran bahasa rata-rata 56,3\%, artinya siswa dan pendidik khususnya guru terkadang menggunakan teknologi dalam proses pembelajaran bahasa. Dari saran-saran hasil angket, para siswa malah beranggapan bahwa teknologi sangat diperlukan untuk mendukung proses belajar mengajar bahasa di kelas, siswa juga sering mengalami kesulitan dalam mencari bahan yang digunakan untuk menyelesaikan tugas pada mata pelajaran bahasa yang dikarenakan masih kurangnya jaringan teknologi internet di daerah Janapria Lombok Tengah.

Wawancara yang dilakukan dengan pihak sekolah dalam hal ini kepala sekolah, waka urusan kurikulam dan para guru di SMAN 1 Janapria ditemukan beberapa informasi tentang kendala yang dihadapi dalam penggunaan teknologi informasi untuk meningkatkan mutu pendidikan pembelajaran bahasa diantaranya adalah :

1. Penguasaan penggunaan teknologi informasi pada tenaga pendidik masih kurang, padahal media ini diperlukan untuk mendukung adanya proses pembelajaran yang kreatif dan inovatif.

2. Para siswa sebagian besar belum menguasai penggunaan teknologi informasi dalam hal ini buku elektronik yang telah disediakan di perpustakaan sehingga perlu adanya peran guru dalam membimbing penggunaan media tersebut.

\section{SIMPULAN}

Berdasarkan hasil analisis dan pembahasan diatas, dapat di simpulkan bahwa motivasi belajar siswa di kelas rata-rata memiliki $65,5 \%$ artinya para siswa di SMAN 1 Janapria ratarata sering memperhatikan guru di kelas dan selain itu para siswa juga memiliki keinginan untuk memecahkan masalah dan berdiskusi kepada para siswa lain untuk proses pembelajaran. Para siswa juga lebih merasa tertarik dengan pelajaran yang ada di kelas karena penyampaian materi yang disampaikan oleh para guru sangat menyenangkan sehingga dapat disimpulkan bahwa para siswa memiliki motivasi belajar yang tinggi.

Sedangkan peran teknologi pembelajaran bahasa rata-rata 56,3\%, artinya siswa dan pendidik khususnya guru terkadang menggunakan teknologi dalam proses pembelajaran bahasa, para siswa malah beranggapan bahwa teknologi sangat diperlukan untuk mendukung proses belajar mengajar bahasa di kelas, siswa juga sering mengalami kesulitan dalam mencari bahan yang digunakan untuk menyelesaikan tugas pada mata pelajaran bahasa yang dikarenakan belum adanya teknologi internet di daerah Janapria Lombok Tengah. 
Berdasarkan dari dua unsur pertanyaan pada penelitian tersebut dapat di buat sebuah simpulan bahwa teknologi mempunyai peran sangat penting dalam meningkatkan kualitas pengajaran bahasa di SMAN 1 Janapria.

\section{PERNYATAAN PENULIS}

Penulis menyatakan bahwa artikel ini belum pernah diterbitkan dalam jurnal manapun

\section{DAFTAR PUSTAKA}

Budiaji, W. (2013). Skala Pengukuran dan Jumlah Respon Skala Likert. Jurnal Ilmu Pertanian Dan Perikanan, 2(2), 127-133. Retrieved from https://osf.io/preprints/inarxiv/k7bgy/

Fadhli, M. (2017). Manajemen Peningkatan Mutu Pendidikan. Jurnal Studi Manajemen Pendidikan, 1(2).Retrieved from http://dx.doi.org/10.29240/jsmp.v1i2.295

Fahrezi, G., \& Susanti, S. (2021). Pengembangan Bahan Ajar Flip Book Kontekstual Berbasis Android Pada Materi Akuntansi Persediaan. Educatio, 16(1), 58-70.

Fridani, Lara; Dhieni, N. (2014). HakikatPerkembangan Bahasa Anak. In Metode pengembangan bahasa (pp. 1-28). Retrieved from http://www.pustaka.ut.ac.id/lib/wp- content/uploads/pdfmk/PAUD4106- M1.pdf

Jusnita, N., \& Ismail, A. (2018). Implementasi Kurikulum 2013 Dalam Pembelajaran Bahasa Inggris di SMP Kota Ternater. Jurnal Pendidikan, 16(1), 1-10. Retrieved from http://ejournal.unkhair.ac.id/index.php/edu/article/view/616

Katuuk, D. A. (2014). Manajemen Implementasi Kurikulum : StrategiPenguatan Implementasi Kurikulum2013. Jurnal Cakrawala Pendidikan, 33(1), 13-26.

Kwartolo, Y. (2010). Teknologi Informasidan Komunikasi dalam proses Pembelajaran. Jurnal Pendidikan Penabur, 14(9), 15-43.Retrieved from http://bpkpenabur.or.id/dokuploads/2015/10/jurnal-No14-Thn9-Juni2010.pdf

Marzal, J.(2014).Desain Media Pembelajaran Bahasa Inggris Untuk Siswa Tuna Rungu BerbantuanTeknologi Informasi dan Komunikasi. Jurnal Tekno- Pedagogi,4(2),3244.Retrieved from https://online journal.unja.ac.id/pedagogi/article/vie w/2291

Moh. Saifulloh. (2012). Strategi peningkatan mutu pendidikan di sekolah. Jurnal Sosial Humaniora, 5(2), 206-218.

Much, I., Subroto, I., Farisa, S., \& Haviana, C. (2016). Sistem Informasi Angket Pengukuran Skala Kebutuhan MateriPembelajaran Tambahan Sebagai Pendukung Pengambilan KeputusanDi Sekolah Menengah AtasMenggunakan Skala Likert. JurnalTransistor Elektro Dan Informatika, 1(2),1-12. https://doi.org/http://dx.doi.org/10.30659/ei.1.1.1 12

Muhson, A. (2010). Pengembangan MediaPembelajaran Berbasis TeknologiInformasi. Jurnal Pendidikan Akuntansi Indonesia, VIII(2), 1-10. https://doi.org/https://doi.org/10.21831 /jpai.v8i2.949

Rogers, E. M. (1986). Communicarion Technology The New Media in Society. Michigan:Free Press. 
Rohmadi, M. (2021). Pemanfaatan Exe Learning Sebagai Media Belajar dari Rumah Selama Pandemi Covid-19. Educatio, 16(1), 37-49.

Sapto, H. (2009). Efektivitas Pemanfaatan Media Audio-Visual Sebagai Alternatif Optimalisasi ModelPembelajaran. Jurnal Edukasi@Elektro, 5(1), 1-10.

Sinambela, P. N. J. M. (2013). Kurikulum

2013 dan Implementasinya dalam pebelajaran. Jurnal Generasi Kampus, 6(3), 17-29. Retrieved from https://jurnal.unimed.ac.id/2012/index.php/gk/article/view/7085

Sudarsana, I. K. (2017). Peningkatan Mutu Pendidikan Agama Hindu Melalui Efektivitas Pola Interaksi Dalam Pembelajaran Di Sekolah. Prosiding Semaya 2, (Semaya II), 134142.

Suryana. (2010). Metodologi penelitian. Triyanto, Eko; Anitah, Sri; Suryani, N.(2013). Peran Kepemimpinan Kepala Sekolah Dalam Pemanfaatan Media Pembelajaran Sebagai Upaya Peningkatan Kualitas Proses Pembelajaran. Jurnal Teknologi Pendidikan, 1(2), 226-238. Retrieved from https://eprints.uns.ac.id/1754/ 